NAGYILLÉS JÁNOS

\title{
Anna Maria van Schurman latin nyelvü költeményei az Opuscula 1652-es kiadásában
}

\begin{abstract}
Anna Maria van Schurman (1607. november 5. - 1678. május 4.) a 17. század szellemi életének egyik legsokoldalúbb és legkiemelkedőbb alakja. Latin nyelvü költeményeinek 1652-es gyüjteményét tesszük itt közzé kétnyelvü kiadásban. ${ }^{1}$
\end{abstract}

Kulcsszavak: Anna Maria van Schurman, 17. századi költészet, női költészet, női költők

A versek itteni a sorrendje az alapul vett 1652-es harmadik, bővített és javított kiadás verssorrendjét követi (adatai a versek után). Az eredeti címeket, amelyek a kor szokásához híven inkább címzések és témamegjelölések, természetesen megtartottuk, az előttük lévő, szögletes zárójelbe tett arab szám az adott vers sorszáma az 1652-es kiadásban. A hiányzó számok magyarázata, hogy ott a kiadásokban Van Schurman egy-egy francia nyelvü költeménye van beillesztve. A versek után található lista a versek szóban forgó kiadásban való helyéről tájékoztat.

\footnotetext{
${ }^{1}$ A publikáció az MTA-SZTE Antikvitás és Reneszánsz: Források és Recepció Kutatócsoport (TK2016-126) támogatásával jelent meg.
} 


\section{[1] Amplissimo Doctissimoque Viro D. Jacobo Catzio}

Vt cygnum resides perhibent intendere voces,

Cum Zephyri albentes attigit aura sinus;

Vtque avis innumeros modulatur gutture cantus

Mirans laeta novum solis in orbe jubar;

Sic tua torpentem laxavit Epistola venam

Pectus ubi afflavit suada diserta meum.

Ast minus hinc justas subeunt mea carmina leges

Dum sponte innumeros non remoranda ruunt.

Iam feror Icariis ignota per aethera pennis,

Fidere non tutis viribus ausa meis,

Mox pavidi devexa subit Phaëthontis imago

Tentans praecipiti carminis ire via.

At meritos virtute tuos mea tangat honores

Pagina, sit laudis pars quotacunque tuae.

Quis, licet ingentis succumbam pondere molis

Obruta, non votis annuat ergo meis?

Hic mecum reliquas sistens Hollandia curas,

Gestiet applausus ingeminasse tibi;

Qualiter exceptus communi Tullius ore

Cum streperet toto mota corona foro.

Quid ni? hoc ingenium, mores, facundia suadent

Et fortuna notas reddit ubique pares.

Hic igitur patrio, vel solum gratulor orbi,

Dum sibi vult plus quam consuluisse tibi;

Nam si tanta premant divinos Munera cantus,

Quid, damna ut reparet, culmen honoris habet?

Si tot delicias perimant sanctosque furores,

Pectora quo vatum fonte scatere solent:

Nonne hic vel gemino tibi Munere gratuler aucto.

Quid vis ingenii par sit utrique tui. 


\section{[1] A méltóságos és tudós Jacob Catz Úrhoz}

Hírlik, a hattyú olyankor hallatja ritka dalát, ha a Zefír fuvalma fehér testét éri: torka számtalan dalt zeng ilyenkor, míg boldogan csodálja az égen a nap első sugarát - így ütött szíven leveled ékesszóló bája s lódította meg vérem lomha áramát. Ám épp ezért nem vetette alá magát versem a kellő szabályoknak: szabadon árad számtalanul s féktelenül. Máris Ikarusz szárnyán suhanok az ismeretlen légben, s bár még bizonytalan, saját erőmre merem magam bízni. De már eszembe is ötlik a rémült Phaëthon alábucskázó képe, míg a költészet nyaktörő útját kísértem. Csak érjen fel versem szépsége megszolgált hírneveddel, bármennyit is kapna csak a te dicsőségedből! Lehet, hogy az irdatlan teher súlya maga alá temet, törekvésemért mégsem kárhoztathat senki. Hollandia most velem együtt feledi többi gondját, s ujjong, hogy kétszeresen zúghat tapsa neked. Tulliust fogadták így hajdan, s beszéltek szerént $\mathrm{s}$ tova róla, $\mathrm{s}$ csak úgy zúgott az egész Forum a köré özönlő tömegtől. S hogy is lenne másképp? A tehetség, jellem, ékesszólás hatása még mindig ugyanaz, s a sors mindenütt ugyanolyan jeleket ad. Most hát, hogy jobban törődik magával, mint veled, együtt örülök hazámmal, vagy akár az egész világgal, mert ha hatalmas megtiszteltetése elfojtaná is isteni dalod, mi minden van a megbecsülés e csúcsán, ami helyrehozza e kárt? Ha kiapasztanák a megannyi gyönyör s szent hevület forrását, mely a költők szívében fel szokott buzogni, nem örvendeznék-e veled éppúgy azon, hogy megbecsülésed kétszeresére nőtt? Ugyan mi érhet fel mindkét féle tehetségeddel? 
O donata tuis felicibus otia amicis

quae Patriae curis, nec sine laude, vacant.

Hinc mecum Batavae veneratur numina Musae

Virgineus, studiis aequior ille chorus:

Hinc, cui nota, venus, vel amoeni gratia dicti

Catziadae tantum fas putat ore loqui,

Huc progressa velut modulis exterrita raucis

Musa, fatigatos linquit in ore sonos,

Vixque repercussis superat vox ultima chordis;

O Patriae et Musis, Vir Venerande, Vale.

\section{[2] Ad D. Barlaeum}

Quas ego pro tanto persolvam Munere grates?

Anne tuis referam carmina carminibus?

Ast mea fama jubet, falsae si parcere fas est,

Scribere Barlaeo nil, nisi scribo nihil,

Neque silens neque respondens

A.M.S.

\section{[3] Clarissimo Viro, D. Andreae Riveto s.}

Tanta tuae, Rivete, viget vox inclyta famae,

Vt solam invidiam velle silere putem.

Si memorare tuas laudes vel convenit hosti,

Conciliet tantum te mihi purus amor.

Ecce igitur properam quam parvula charta salutem

Dicit, Amicitiae candida signa meae. 
Ó, mi boldogok barátaid, hogy minden idő, mely a haza gondjaival való dicséretes törődés után marad, nekik szenteled! Mostantól a híres szűzi kar velem tiszteli Batavia Múzsájának erejét, s persze nálam inkább felér tudásodhoz; mostantól, ki tudja, mi a báj, mi kellem van az édes szóban, úgy gondolja, csak Katz nyelvén szólhat. Eddig tartott velem a Múzsa, mintha rekedt hangom megrémítette volna, hangja kimerült s elhal ajkán, s utolsó hangja bágyadtan csendül megpendített húrjaimon: Isten hozzád, Hazánktól és a Múzsáktól tisztelt férfiú!

\section{[2] [Caspar van] Baerle Úrhoz}

Hogy törlesszem hálám ekkora ajándékért? Tán verseidért verseim adjam cserébe? Csakhogy a hírem - már ha alaptalan hírt érdemes kímélni - azt parancsolja, egy Barlaeusnak ne írjak semmit, csak tényleg a 'semmi'-t.

Nem is hallgattam, s nem is válaszoltam, A.M.S.

\section{[3] Üdvözlet a hírneves André Rivet Úrnak}

Híred ismert hangja oly hatalmasan zeng, Rivetus - vélem, csak valami irigy akarhatja, hogy hallgasson el. Ha még ellenséged is csak dicsőségedről tudósíthat, hozzám a színtiszta szeretet kössön. Lám, e mégoly apró lapocska sietve mond üdvöt, s mégis fénylő jele barátságomnak.

Kinek erényeidnél semmi sem kedvesebb 


\section{[4] [hozzá szóló]}

Annae Mariae a Schurmans Unioni. Ut minus lateat.

Quo te, Nympha, cui tam custodita, quousque

Subtrahis, et muta laude sepulta lates?

Caelatae virtutis onus fit inertia, fit nox,

Fit gravis aeternae mortis imago quies.

Prodi parca Venus, partuque Batava marino

De tot virtutum nascere, diva, mari.

Sol in virgine plus satis est; in Sole rogamus

Virgo sit, accendas orta, fugesque diem.

[5] Ad occultum Apollinis cujusdam ad lucem me provocantis Oraculum Responsio.

Magnum Musa virum sonat; utque ego sim quoque vates, Ingenium Constans da mihi Phoebe tuum.

Ast quo jure meum poscit clarescere nomen, Cum pro me causam, qui latet, Autor agat.

[6] A. Mariae a Schurm. Epigramma in Nobilissimi praestantissimique Viri, D. Constantini Hugenii Opus - Diurnum. Quod in gratiam lectissimae suae quondam Conjugis Dnae. Susannae a Baerle conscripsit.

Quaeris an haec claram mereantur carmina lucem,

Quis neget? Hanc poscit Nobilis UMBRA sibi.

$\mathrm{Nec}$, si forte velis, potes occultare diurnum,

Cum natura tibi Phoebe, repugnet, Opus.

\section{[7] Ad Illustrem Virum Zulichemii Dominum.}

Cur me mortalem poscunt tua carmina testem,

Quae testes Clarias promeruere Deas?

Sed tua jure meas poscunt sibi munera grates,

Quas tibi cum nequeam reddere, nomen habe. 


\section{[4] Anna Maria van Schurmanhoz, a Gyöngyszemhez. Hogy ne rejtőzködjék.}

Hová s még meddig vonulsz el, Nimfa? Mi tart fogva téged? Miért temetkezel néma dicsőségbe? Még a kőbe vésett erénynek is árt a tétlenség, árt az éj, a pihenés az örök halál nyomasztó képmása. Állj elő, szerény Vénusz, szüless meg a tengerből, bataviai istennő, megannyi erényed tengeréből! E hajadonban túl rég ragyog nap, kérjük, hogy ő ragyogjon a napon: kelj fel, gyújtsd meg s ragyogd túl a napvilágot.

\section{[5] Válaszom egy bizonyos Apolló fényre csalogató homályos jósszavára.}

Nagyszerű férfira vall a Múzsa zengő szava; Állhatatos Apolló, add nekem tehetséged, hogy vátésszé lehessek én is! Ám mi jogon követeli szerzője, hogy nevem hírre kapjon, ha maga is névtelenül képviseli ügyemet?

[6] Anna Maria van Schurman epigrammája a nemes és előkelő Férfiú, Constantijn Huygens Úr müvére, a Diurnumra. Írta kiváló néhai hitvese, Susanna van Baerle kedvére.

Azt kérded, e versek megérdemlik-e a fényes napvilágot. Ki tagadná? Ezt követeli magának a nemes árny. S még ha akarnád, sem tudnád rejteni napi munkád, Phoebus: természeted szegülne ellened.

\section{[7] Zuilichem Méltóságos Urához}

Mért hívnak engem, halandót tanúul verseid, holott kiérdemelték a klároszi istennők tanúságát? Jótetteid mégis joggal kívánják hálám - s mert a viszonzásra képtelen vagyok, hálaszóm legyen tiéd! 
[8] A. M. a SCHURMAN.

Ad Epramma Viri השָם Donstantini Hugenii Zulichemi Toparchae quod sic habet. ${ }^{1}$

Nomen habe, Schurmanna canit. Lepidissima virgo!

Nomen habes nequiit dicere, dixit habe.

$\mathrm{O}$ si ridenti potis esset dicere verum,

$\mathrm{Si}$, quod habet, dando nomen habere daret!

[9] Responsio Annae Mariae a Schurman.

Hugenio cum non sit, nomine, clarior alter,

Quis melius, dando nomen habere, daret?

\section{[10] ALIUD.}

Anne bonum credat, nequeam cum solvere, nomen?

Quis dare, quaeso, bonum, quo caret ipse, potest?

\section{[11] ALIUD.}

Quare tuum, Constans, nostro vis cedere nomen?

Sic mihi, mutato nomine, nomen eris?

[12] Ad serenissimam Angliae Reginam e puerperio nuper egressam A. CID ID XXXV. tempore hyberno

ECHO. Alludens ad insignia REGNI BRITANNI tribus rosis figurata.

Quae tibi nunc gelido miracula nata Decembri

Quippe moras steriles Flora perosa? Rosa.

Sortem vicisti communem: Anglisque perennis

Arridet veris spes generosa. Rosa.

Sic genitrix sis saepe Deum. Sors statque caditque

Dum paris, aut cessas Diva operosa. Rosa.

\footnotetext{
1 'ansey hasem' (héber) = Isten embere. A héber fordulat első szavát van Schurman latinra fordítva, viri-vel visszaadva használja. A kifejezés megfejtéséért Bar Leshemnek (Ben-Gurion University of the Negev - בנגב גוריון-בן אוניברסיטת) tartozom köszönettel.
} 


\section{[8] Anna Maria van Schurman}

Constantijn Huygens Úr, Zuilichem Ura epigrammájára, mely így szól.

Schurman dala így szól: Légy hírneves! Finom müveltségü hajadon! Azt hogy, Hírneves vagy, nem mondhatta - így mondta hát: „Légy!” az. Ó, ha nevetve kimondhatnók az igazságot, $\mathrm{s}$ ha azt adva oda, ami nekünk már van, másnak is adhatnánk nevet!

\section{[9] Anna Maria van Schurman válasza.}

Bár, nincs, kinek neve Hugeniusénál jobban ragyogna, jobbat ki adhatna annál, ha azzal, hogy ad, nevet adhat?

\section{[10] Másik.}

Úgy hiszi hát, jó a nevem, bár meg sem fizethetem? Mégis ugyan ki adhatna másnak olyan javakat, melyeknek maga híján van?

\section{[11] Másik.}

Miért teszel úgy, Constans, mintha neved nem érne fel az enyémmel? Így, ha nevet cserélünk, az én nevem leszel?

[12] Anglia Felséges Királynőjének, aki nemrég jutott túl a gyermekágyon 1635 telén

Visszhang, mely a Brit Királyság három rózsát ábrázoló címerére utal

Zord december idején született csodás gyermeked - Tán Flora gyülöli a terméketlen tétlenséget? - Rózsa. Legyőzted a közös emberi sorsot - az angolokra az örök tavasz nemes reménye mosolyog. Rózsa. Légy hát még sokszor Istenek szülője. A sors hol kegyel, hol nem, míg szülsz vagy míg pihensz, serény istennő. Rózsa. 
[13] Inclytae et antiquae urbi Trajectinae Nova Academia nuperrime donatae gratulatur. Anna Maria a Schurman.

Tu quae lege potens agris dominaris, et altis Moenibus, et moles tollis ad astra tuas.

Cui prior est cura ingeniis clarescere, et armos Palladis ignavam pellere Barbariem.

Nil te cornigeri moveant dispendia Rheni.

Quodque ingrata Lares liqueris ${ }^{2}$ unda tuos.

Nil moveant suspensa avidae commercia turbae,

Quaeque dabat volucres sors vaga divitias.

En subeunt refugo potiores flumine lymphae,

$\mathrm{Vt}$ tua perpetuis fontibus arva rigent.

Omnia laeta vides nitido splendescere vultu,

Et jam deliciis sistere vota suis:

Quippe novos facilis reserat tibi Pegasus amnes

Blandaque Castalias Musa ministrat aquas.

Hinc bibet indigena, et sitientes Nectara Belgae,

Hinc bibet et geminus qua patet usque Polus.

Hinc quoque Mystarum facunda per ora Minervae

TRAJICIES placidas (munera mentis) opes.

Ast quae (forte rogas) agitant tua pectora curae?

Non haec Virgineis pervia Sacra choris.

Omnibus hic seritur, metiturque, ut amica quieti

Alma Themis discors arceat Orbe Chaos,

Vtque pio irradiet divina Scientia cultu,

Et caleat summo qualibet Ara Deo.

Hic scopus, hic sisto; satis inter publica Mundi

Gaudia laetitiae signa dedisse suae.

Salve o spes Populi, Generis melioris origo,

Cui Sol Iustitiae Lumina prima dedit:

Salve iterum attonitis Lux orta novissima seclis

Ne Sol Iustitiae vergat ad ima tibi.

2 jav. <liquerit $>$ 


\section{[13] Köszönti Utrecht híres és ősi városát, mely nemrég új Akadémiát kapott. Anna Maria van Schurman}

Törvényeid erejével uralod földjeid s magas falaid, s épületeid égig érnek. Legfőbb gondod, hogy tehetségeid ragyogjanak, s hogy Pallas keze elüzze a tunya Barbárságot. Ne bánd, hogy neked nem hajt hasznot a szarvas Rajna, s hogy Lárjaidat hálátlan habja cserben hagyja. $\mathrm{Ne}$ bánd, hogy a kapzsi csőcselék itt felfüggeszti a kereskedelmet, s hogy a szeszélyes sors neked tovatűnő gazdagságot ad. Nézd csak: a folyó visszafordul, erősebb víz árad amaz helyébe, s örök forrásaival öntözi szántóidat. Látod, minden boldog, ragyogó orcája fénylik, s vágyaik örömükbe fordulnak, hisz a könnyüléptü Pegasus új folyamokat fakaszt neked, s a nyájas Múzsa ontja Castalia vizét. Isznak belőle honfitársaink s a nektárt szomjazó Belgák, iszik belőle mindenki, ahol csak laknak Északon s Délen, s innen HOZOD ÁT Minerva beavatottjai ékesen szóló ajkán szelíd hatalmad, a szellem ajándékát. $S$ ha tán kérded, miféle gond gyötri mégis a szíved: az, hogy a szentélybe nem léphet a Hajadonok Kara. Mindenkinek vetnek itt, s mindenkinek aratnak, hogy a tápláló Themis, a béke barátja tovaüzze a világról a viszálykodó Zürzavart, $\mathrm{s}$ hogy felragyogjon az isteni Tudomány odaadó müvelése, s lobogjon a tüz a Leghatalmasabb Isten oltárán. Célhoz értem, itt megállok - saját boldogságának már eléggé hangot adott a világ öröme közepette. Légy üdvöz, népünk reménysége, egy jobb nemzedék kezdete, melyre az igazság Napja első sugarait vetette, légy újra üdvöz, kábult századokra újonnan virradó Világosság, soha le ne áldozzon egedről az igazság Napja. 
[15] Magni ac generosi animi HEROINAE GORNACENSI, Causam sexus nostri fortiter defendenti gratulatur Anna Maria a Schurman.

Palladis arma geris, bellis animosa virago;

Utque geras lauros, Palladis arma geris.

Sic decet innocui causam te dicere sexus,

Et propria in sontes vertere tela viros.

I prae Gornacense decus, tua signa sequemur:

Quippe tibi potior, robore, causa praeit.

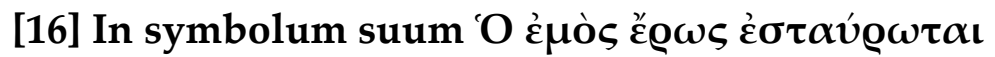

Quis non sollicito Christum veneretur amore?

Quem simul Echo omnis conscia clamat. Amat.

Hic nos solus amat qui sanguine pascit amantes;

Tartaraque edomuit qui moriens. Oriens.

Hunc igitur sapiens casta pete mente puella,

Nitere hoc sponso, nec tibi fide. Fide.

A.M.a SCHURMAN

[17] A. Mariae Schurman AD HXOY 2 DOUSICAS Provocatio Num a Nobilissimo Viro D. Dousa provocata, in lucem prodire debeat, necne?

O Vos Dousarum resonantes Carmina Nymphae,

$\mathrm{Ne}$, quid me deceat, dissimulate; Late.

[18] Clarissimo Ornatissimoque Viro, D. G. Staackmanno.

Si veneranda docet frontem obvelare vetustas,

Et fugere ignotum virginis ora forum:

Cur alia est animi natura bonis, hominum quae Arbitrium fugiunt, sufficiuntque sibi?

A.M. a SCHURMAN 
[15] Anna Maria van Schurman üdvözli a nagy- és nemeslelkü [Marie] de Gournay hősnőt, nemünk ügyének bátor védelmezőjét

Pallas fegyverzetét viseled, harcedzett hajadon, s bár babérkoszorúsan, Pallas fegyverzetét viseled. Illő, hogy így képviseld ártatlan nemünk ügyét, s fordítsd saját fegyvereit a bűnös férfiak ellen. Járj az élen, Gournay ékessége, s zászlód követni fogjuk, mert előtted meg az ügy jár, mely még nálad is erősebb.

\section{[16] Saját mottójára: Szeretetem keresztre feszítve}

Ki ne tisztelné Krisztust aggályos szeretettel? Minden Echo őt kiáltja ennek tudatában: SZERET. Csakis ő szeret minket, ki vérével táplálja az őt szeretőket, s ki leigázta a poklot halálával. Ő NAPKELETÜNK. Tiszta szíved fordítsd hát felé, bölcs leány, rá mint jegyesedre bízd magad, s ne magadban higgy. HIGGY.

[17] A. Maria Schurman kihívása [Dirk Van der] Does ekhóira Nyilvánosság elé álljon-e a Nemes D. Dousa Úr kihívására, vagy ne?

Ó ti nimfák, ki Dousa dalait visszhangozzátok: ne titkoljátok, mit illendő tennem! Rejtőzz!

\section{[18] G. Staackmann Úrnak, a nevezetes és jeles férfiúnak}

Ha tiszteletreméltó őseink arra tanítanak, hogy leplezzük érzéseinket, s hogy egy hajadon orcája kerülje az ismeretlen társaságot, miért más egyes derék hölgyek lelki alkata, akik nem törődnek az emberek megítélésével, s megelégednek önmagukkal?

A.M. van Schurman 


\section{[19] Apologia Annae Mariae a Schurman}

Contra erroneos quosdam rumores, quibus propter nominis Schurmanni homonymiam, Astraeam d'Urse e Gallico in Belgicum sermonem vertisse creditur.

Cur mea lascivis praetexi nomina chartis

Fama est? Cur meruit fama sinistra fidem?

An dubiae tantum poterit fallacia vocis,

Credar ut ingenium deseruisse meum?

Haud eandem curant omnes. Et myrtea serta

Quae nunquam merui, tale meretur opus.

Non dominae invideo, grati ferat ipsa laboris

Praemia: diversae nos tenet artis amor.

Id monuisse juvat; ne me misisse Camoenas

Iactitet invictas sub sua sceptra Venus.

Nec violasse tuas leges Astraea putabor:

Quippe suum tribui cuilibet ipsa jubes.

[20] Epigramma in Historiam Gelricam Clarissimi Viri, Joh. Isaaci Pontani.

Palladias artes quondam coluere Sicambri, Et sors clara toga, claraque Marte fuit, Sed jam Lethaeis ingrato tempore lymphis

Mersa fere antiquae gloria gentis erat.

Hanc pius immemori revocat Pontanus ab orco,

Et reddit patrio lumina tanta solo.

Hic sacra consilia, et magnorum effata virorum,

Gestaque Francorum nomine digna refert:

Quaeque olim magnis animis dedit aequa vetustas

Praemia mirari secula nostra facit.

Sic simul aeternos virtuti jure triumphos

Vindicat, et populo prisca trophaea suo.

Annon qui toto parat haec spectacula mundo,

Dignus ut applausus hinc prior ipse ferat?
A.M. a Schurman 


\section{[19] Anna Maria van Schurman apológiája}

bizonyos téves híresztelésekkel szemben, melyek szerint a Schurmann név azonossága miatt azt hiszik, ő fordította franciáról flamand nyelvre d'Urse Astraeáját.

Miért kapott szárnyra a hír, hogy nevem egy pajkos könyv címlapján szerepel? Miért hittek e sanda hírnek? Tényleg el tudja még érni egy kétes hang csalárdsága, hogy elhiggyék, faképnél hagytam tehetségemet? De nem mindenki törődik vele. $S$ egy ilyen mü mirtuszkoszorút ér, melyet én soha nem érdemeltem ki. Nem irigykedem erre a hölgyre, vigye csak kedves munkája jutalmát: én másféle múvészetet szeretek. Jónak látom, hogy emlékeztesselek: még majd Venus elhencegne vele, hogy legyőzhetetlen Camoenáimat átengedtem az ő hatalmának. Nem is hiszik majd, Astraea, hogy megszegtem törvényeidet, hiszen te magad parancsolod, hogy mindenkinek meg kell adni, ami jár neki.

\section{[20] Epigramma a nevezetes férfiú, Johannes Isacus Pontanus Gu- elders történetére}

Hajdan a sicamberek Pallas művészetét űzték, s dicső volt sorsuk békében s háborúban, de hálátlan korunkban ez ôsi nép dicsősége már szinte a Léthe vizébe veszett. Ezt idézi meg a jámbor Pontanus az alvilági feledésből, s szülőföldjét újra ragyogó fénybe borítja. Nagyszerü férfiak szent szándékait s szavait $\mathrm{s}$ a frankok említésre méltó tetteit tárja fel, hogy amit hajdan nagy lelkeknek szánt a méltányos régmúlt, jutalomként csodálja a mi korunk. Épp így ő is joggal követel az erénynek örök diadalt $\mathrm{s}$ népének ősi dicsőséget. Vagy tán nem lenne méltó rá, hogy előbb maga arasson tetszést abból, hogy az egész világnak elkészíti e látványosságokat? 
[21] Memoriae Celeberrimi Historici et Jurisconsulti Arnoldi Buchelii Eruditissimas Notas in Historiam Ultrajectinam Una cum vita finientis.

Gratia dum doctae fuerit mihi grata Minervae, Et tua, Bucheli, gratia dulcis erit.

Nam quae mors homines inter commercia tollit,

Vivere te memori pectore nulla vetat.

Vt fueras quondam priscae virtutis imago:

Sic mihi jam virtus semper imago tui est.

Non ego tam celebris laudes meditabor amici.

En claret propriis, quas dedit ipse, Notis.

Qui vitam patriae et perituris addidit annis, Is meruit nunquam, post sua fata, mori.

A.M. a Schurman

[22] In Reverendi, Nobilis Doctissimique Viri, D. Andreae Riveti S.S. Theologiae Doctoris Vindicias Mariae matris Domini.

Omnia sacrilegus tandem pervaserat error, Et jam Roma potens terram miscebat Olympo:

Nec quaenam facies venerandae Virginis esset

Dignosci poterat: vultusque erat unus utrique Et Matri et Soboli, similisque per omnia cultus.

Viderat haec ardens animis Rivetus, et una

Detrahit has larvas, propriisque coloribus ornat

Virgineam frontem, primo de fonte petitis.

Quin male conficti subvertit numinis aras,

Et meritos (quales genuina modestia suadet)

Restituit mundo magnae genetricis honores.

Hic, si forte placet nitidis depicta tabellis

Simplicitas, autor toto celebrabitur orbe.
A.M. a Schurman 


\section{[21] A hírneves történetíró és jogtudós, Aernout van Buchel emlé- kének, aki tudós Jegyzeteit Utrecht történetéhez életével együtt fe- jezte be}

Míg kedves lesz nekem a tudós Minerva kegye, a te kegyed is kedves lesz nekem, Buchelius. Mert bár a halál elszólíthatott az emberi világból, nem tilthatja meg, hogy élj nem feledő szívemben. Mint te voltál hajdan a régi erény mintaképe, úgy az erény bennem immár mindig a te képedet idézi fel. Nem is írok én himnuszt ily híres barátról - tegyék híressé, melyeket ő írt, saját Jegyzetei. Életét hazájának s a múló éveknek szentelte, s kiérdemelte vele, hogy, ha végzete beteljesedett is, soha ne haljon meg.

A.M. van Schurman

[22] A tisztelendő, nemes és tudós André Rivet Úr, teológiai doktor $A z$ Úr anyja, Mária védelme címü müvére

Végül az istentelen tévelygés mindenüvé elhatolt, s már a hatalmas Róma is összekeverte a földet és a mennyet, s nem lehetett már felismerni a tiszteletreméltó Szűz orcáját, egy volt már arca az Anyának és Fiának, s mindenben hasonló volt tiszteletük. Látta ezt a lánglelkű Rivetus, lerántotta róluk az álorcát, s hozzá illő színekkel festette a Szűz arcát, éspedig az első forrásból merítette őket. Mi több, felforgatta a hamisan kigondolt isten oltárait, s visszaadta a világnak az Istenszülő méltó tiszteletét, melyet igaz szerénysége sugallt. Mindennek véghezvivőjeként az egész világ ünnepelni fogja, ha tetszésre lel, ahogy ragyogó lapjain festi az egyszerüséget.

A.M. van Schurman 


\section{[23] Nobilissimo Doctissimoque Heroum D. Claudio Salmasio Felicem e Galliis redditum gratulatur Anna Maria a Schurman.}

Hospes ave Batavis jam tandem reddite terris:

Quin orbis resonet: Battavus Hospes ave.

Quem Regum illecebrae, quem tot promissa Potentum

Reddere vel patrio non potuere solo.

Hinc tibi, Salmasi, quos non referemus honores?

Qui nos praetuleris gratis honore tuis.

Nunc quoque te fama est, pro nostris fortiter aris,

Moliri summum Relligionis opus.

Pessimus interpres veteris Baronius aevi

Protinus ultrices sensit adesse minas.

Et licet ingentes imitetur mole gigantes,

Crede mihi, calamo mox cadet ille tuo.

Quid ni? cum septem geminae praecordia Lernae

Vix animam, ante tuo fulmine tacta, trahant.

Hoc tibi certamen merito decernit Olympus,

Ut paret Alcidi digna trophaea suo.

Quod si vota mei non dedignabere sexus,

Is quoque grata tibi praemia sponte feret.

Blanda puellarum comitabitur aura triumphos;

Virgineusque canet carmina laete chorus.

Haec agitanda viris potius si cura videtur,

Est tamen a nostro non aliena foro.

Proque Lupa Caesar, cum tu pro virgine certes,

Cur non virgo tibi laurea serta daret?

Ultrajecti III. Non. Jan. MD[C]XLIV 


\section{[23] A hősök legnemesebbikének s legtudósabbikának, Claude Saumaise Úrnak Anna Maria van Schurman szerencsét kíván abból az alkalomból, hogy hazatért Franciaországból}

Légy üdvöz, vendég, végre-valahára visszaadva Batavia földjének - sőt zengje az egész világ: Légy üdvöz, bataviai vendég. Még hazád földjére sem téríthettek vissza sem királyok csábítása, sem hatalmasok ígéretei. Van-e olyan megbecsülés, amit ne érdemeltél volna ki ezzel, Salmasius? Párját ritkító megbecsülés ez irántunk, Salmasius! Ellenszolgáltatás nélkül becsültél többre minket honfitársaidnál. Most is hírlik, bátran építed oltárainkért a Hit hatalmas épületét. Baronius, a régi kor legsilányabb tolmácsa tüstént észlelte, hogy itt a fenyegető bosszú. Hadd idézze csak tömege az irdatlan gigászokat, hidd el, hamarosan tolladtól esik el. Már hogy ne esne el? Bárha keblében a hétfejü lernai szörny szíve dobogna is, lelkét aligha mentheti, ha mennyköved lesújt rá. Méltán adta neked a Menny e viadalt, hogy Herkuleshez méltó győzelmi jelet készítsen vele neked. Ha méltatlannak nem veszed nemem hő imáját, kedves lesz az a jutalom is, melyben az részesít. Diadalmeneted hajadonok lelkes csapata raja kíséri, s szüzi kar zengi majd boldog himnuszait. Ha meg úgy tetszik, ez inkább a férfiak dolga, akkor sem idegen az asszonyi körtől. Miért is ne nyújthatná neked egy hajadon a babérkoszorút egy kéjnő helyett, hiszen egy szüzért harcolsz.

Utrecht, 1644. január 4. 


\section{[24] Reverendo, Clarissimo, Doctissimoque Viro, D. Friderico Spanhemio S.P.D. Anna Maria a Schurman}

Quid me, Spanhemi, revocas Heliconis ad amnes,

Neglectamque jubes sollicitare chelyn?

Non mea, crede mihi, sublimi carmina cedro

Nec sunt aspectus lumine digna tui.

Attamen invitae minus est litare Minervae,

Quam quae dona cupis parva negare tibi.

Te duce sponte sequar; tua nam vestigia coeli

Monstrabunt, veluti lactea signa, viam.

Saepe olim veteris ego sum mirata Pelasgos,

Queis data Musarum gloria prima fuit.

Pulchrius Hesiodo, vel magno majus Homero,

Iudice me, nullum viderat orbis opus.

Iam mera credebam divina oracula voces,

Quas celebrat septem Graecia docta virum.

Iam mihi praeclaro radians Academia vultu,

Vertice stelligerum tangere visa polum.

Attica quid memorem, quid nomina magna Lycei?

Illa salutiferi sideris instar erant.

Quin Stoa invictae cultrix quondam inclyta mentis,

Flexerat in cultum pectora nostra suum.

Haec ego tum cura et studio jactabar inani,

In medio quaerens littora tuta mari.

Ast ubi dignata est divini gratia verbi

Clarius in nostra spargere mente jubar:

Protinus ut stellae pereunt Titanis ad ortum,

Palladis obscurae sic periere faces.

Scilicet augustos humana scientia fasces

Non potuit tantae non subiisse Deae.

Tum mea nectareo humectans praecordia succo,

Coelestis visa est sic mihi Suada loqui:

Quid facis, o demens Virgo, quid quaeris inani

Gutture Tantaleos non saturanda dapes? 


\section{[24] Üdvözlet a tisztelendő, nemes és tudós férfiúnak, Friedrich Spanheim Úrnak Anna Maria van Schurmantól}

Spanhemius, miért hívsz vissza a Helikon árjához, hogy vegyem fel újra félretett lantomat? Hidd el, nem méltók dalaim az égbetörő cédrushoz, sem hogy szemeid illessék. Mégsem oly nagy fáradság áldoznom Minervának, még ha az nem is akarja, mint megtagadnom neked az apró ajándékot, amelyre vágysz. Örömest követem vezetésed, mert nyomaid, mint valami Tejút, az égbe vezető utat mutatják. Gyakran csodáltam régebben az ősi Pelasgokat, mert nekik jutott először a Múzsák dicsősége. Ítéletem szerint nem látott a föld sem szebb munkát Hésziodoszénál, sem nagyobbat Homéroszénál. Hittem, tiszta isteni igazság minden szó, melyet a tudós Görögország a hét bölcséként ünnepel. Úgy láttam, a sugárzó Akadémia ragyogó orcája a csillagos eget veri. Minek említsem Attikát, minek a Lyceum hatalmas neveit? Az Üdvösség csillagát jelentették nekem. S persze a Sztoa, a legyőzhetetlen elme híres művelője tiszteletet ébresztett szívemben. Akkoriban gondos, de hiábavaló tanulmányaim tárgya csak ez volt, s a nyílt tengeren kerestem biztonságos kikötőt. Ám mihelyt Isten igéjének kegye méltónak talált, hogy elmémre szórja ragyogóbb sugarát, úgy hunytak ki mellettük Pallas fáklyái, ahogy a csillagok hunynak ki rögvest napkeltekor. Hogy is ne hódolt volna be az emberi tudás ekkora istennő fenséges hatalmának. S egyszer csak a mennyei Suada elárasztotta szívem nektárjával, s e szavakkal lépett elém: „Mit művelsz, esztelen Leány, miért óhajt torkod hiábavaló tantaloszi étkeket, melyektől soha jól nem lakhat?" 
Crede mihi insipidas, quas tellus parturit, undas

Non animi ardentem posse levare sitim.

Quippe sui similis non est mortale quod optat

Spiritus, hoc unum pagina sacra dabit.

Haec docet immensum complecti mente Tonantem,

Machina quem mundi non tamen ipsa capit.

Hic veram invenies requiem, variasque potentis

Fortunae poteris spernere tuta vices.

Talia nec Samii docuere silentia Mystae,

Nec placido Actaeus prodidit ore Senex:

Non haec legiferi memorant effata Lycurgi,

Nec sapit haec sapiens veridicusque Solon:

Deficit hic acies divina Platonis; hebescit

Magnum naturae lumen Aristoteles.

Quin bona mortalis perituraque munera vitae

Hi potius summo substituere bono.

Et quoniam (ut perhibent) mors ultima linea rerum

Mors merito hic summum creditur esse malum.

O vitam miseram! brevior quam terminus aevi

Claudit et aeterno nox premit atra jugo:

Aut potius faustam! celeri devolvere fuso

Stamina cui Lachesis non remoranda sinit.

Aspice magnanimos Brutos, rigidosque Catones,

Vt proprias armant in sua fata manus.

Quis furor est voluisse viros, fortesque videri,

Nec vitae ingratas sustinuisse moras?

Quis furor hanc lucem toties dixisse beatam,

Vivere si poena est, siqua perire salus?

Desine mirari speciem virtutis honestam,

Quae genium vitii splendidioris habet.

Quod si Cecropiae possent a funere chartae

Aurea discipulis secla referre suis:

Et si lecta suo non illusisset amico

Pagina, praecipiti quem dedit ipsa neci: 
Higgy nekem, ízetlen a földből fakadt víz, nem enyhítheti a lélek tikkasztó szomjúságát. A lélek önmagához hasonlatos, amit óhajt, az sem halandó, s ezt az egyet a Szentírás adhatja csak meg neked. S ennek tanítása, hogy az elme, bármily mérhetetlen, befogadja Istent, ki az egész teremtett világban sem fér el. Itt lelsz igaz nyugalomra, s bizton feledheted a hatalmas Fortuna fordulatait. Ilyesmit nem tanítottak sem a szamoszi papok, sem az Attikai Vén szelíd ajka nem szólt róla, ilyet a törvényhozó Lycurgus szava sem említ, s ehhez az igazmondó bölcs Szolón sem ért. Itt vereséget szenved Platón mégoly isteni serege, s belesápad a természet ragyogó világa, Arisztotelész. Hiszen ők a véges élet múló javait tették meg legfőbb jónak, s minthogy - úgy mondják - a halál a lét végső határvonala, méltán hitték ekkoriban, hogy a halál a legfőbb rossz. Milyen nyomorú az élet! A rövid idő határa zárja, s már rajta is a fekete éj örök igája. Vagy mégis inkább jó... Szála lefut sebesen pergő orsóján s Lachesis nem engedi tovább érni. Lám csak, nagylelkü Brutusok s szigorú Catók fegyverzik kezüket saját vesztükre. Mily esztelenség, hogy férfinak, s hozzá bátornak akarnak tünni, s ha nem kedvükre való, eldobják az életet! Mily esztelenség, hogy annyiszor boldognak mondták ezt az árnyékvilágot, ha büntetés élni, s a boldogság a halál! Ne csodáld az erény e tisztes faját, mert egy ragyogó bűn szelleme hatja át! Ó, ha Cecropia könyvei a halálból szólhatnának tanítványaiknak aranykorukról, s ha elolvasott lapjaik nem űznének tréfát barátjukból, akit maguk vettek rá az idő előtti halálra. 
Quid praeter formas rerum exhibuisset inanes,

Quas rata felices reddere posse rogos?

Scilicet hoc primae latuit clementia causae,

Vivere qua sine mors, qua duce vita mori.

Sint porro Elysiis solatia dulcia campis,

Misceat et Phrygius pocula laeta puer;

Sitque ingens Heroum animis post fata voluptas,

Sidera et aethereas pervolitare domos:

Et quacunque levem ludat sub imagine turbam,

Fac dare, quae fingit, Musa prophana queat:

Quid nisi corporei meditetur gaudia sensus,

Gaudia vel blandus qualia somnus habet?

Mitto quod effraenes colat, ut sua Numina, mores,

Sacrilega turpes dum facit arte Deos.

At quae delapsa est alto Sapientia coelo,

Altius humanis mentibus una sapit.

Haec licet ingentes animos exuscitet; atqui

Plura tamen votis conferet illa tuis.

Nec jubet aeternam tantum sperare salutem;

Sed potis ante atram quemque beare diem.

Singula quid referam, quid tentem vocibus aures?

Talia sentiri non nisi mente solent.

Tunc ego, des veniam teneris placabilis annis,

Diva precor, par est me tua jussa sequi.

$\mathrm{Ne}$ te festines oculis subducere nostris,

Neve tuum prima fronte referre gradum.

Illa tamen contra, mea sors et origo morari

Longius hac, inquit, me regione vetant.

Sunt mihi non pauci rarae pietatis Alumni,

Queis dedimus nostri pandere jura fori.

Quod si sacra cupis tanti cognoscere regni,

Et quae Lethaei non rapit unda lacus;

Quaeque locis non sit frustra didicisse beatis

Hos juvet in dubiis consuluisse viros. 
Mi mást kaphatna tőlük, mint a létezők üres formáit, s még úgy hiszi, hogy majd ezek teszik boldoggá a halált... Lám ennyire elrejtőzött az Első Ok kegyelme, mely nélkül élni halál, ám a halál élet, ha ez vezérel. És csak várjon édes vigasz az elíziumi mezőkön, s keverjen víg kupákat a fríg fiú, s hatalmasan gyönyörködjön a halál után a Hősök lelke, hogy röpködhet a csillagok és égi házak között, s játszódjék bármilyen szín alatt a lebegő tömeg, s tegyük fel, a földi Múzsa képes megadni mindazt, mit kitalál, de mi van, ha csupán földi örömöket önt dalba, vagy olyanokat, amelyek szép álmainkban léteznek? Azt nem rovom föl neki, hogy zabolátlan erkölcsöket tisztel isteneként, s közben szentségtörő művészete gyalázza az isteneket, ám a magas Mennyből alászállott Bölcsesség értelme egymaga mélyebbre hatol minden emberi tudásnál. Ő, ha mégoly magasztos lelkesedésre lobbant is, imáidnál mégis többet ád neked. Nemcsak az örök üdvösség reményét ébreszti fel benned, hanem van arra is ereje, hogy még gyásznapod elött boldoggá tegyen. Minek mind felsorolnom, minek fárasszák szavaim füledet? Ilyesmit felfogni csak a lélek szokott. Kérlek is, istennő, légy elnéző, s bocsáss meg zsenge koromnak: úgy illő, hogy kövessem parancsaidat. Ám ne siess annyira, szem elől ne tévesszelek, s lépteid el ne tünjenek előlem. Ő így válaszolt nekem: "Sorsom s hazám sem hagy itt hosszan időzni, ám nem egy párját ritkító jámborsággal megáldott növendékem van, akinek megadtam, hogy világom szabályait feltárja. Ha vágyol megismerni hatalmas birodalmam szertartásait, s mindazt, amit nem ragad el a Léthé tavának habja, s mindazt, amit érdemes megtanulni, hogy a boldogok helyére érkezz, kételyeid közepette e férfiaknál keress eligazitást." 
Dixerat, et stimulos acres in corde reliquit, Incenditque sacro pectus amore sui.

Hinc, sibi praecipuos quos designarat amicos,

Non potui summa non coluisse fide.

Hos inter, stellas velut inter Luna minores,

Eminet et Nomen sic, Frederice, tuum.

Te praeeunte canam majora, et forte cothurno

Non indigna gravi, te praeeunte, canam.

Aemula ceu pulsis resonat convallibus Echo:

Sic referam dociles ad tua verba modos.

Gorgonei valeant fontes, doctaeque Sorores,

Tu mihi Parnassus tu mihi Phoebus eris.

Ultrajecti XI. Kal. Febr. MDCXLIV

[26] IN OBITUM Nobilissimi \& Venerandi Theologi JOHANNIS POLYANDRI à KERCHOVEN.

Fortunate Senex, quondam dum vita manebat

Quae sors non votis risit amica tuis?

Quis plures meritis dignos jactabit honores,

Contulit in Myftas quos toga sacra suos?

Quis natos vidit magni felicius aulam

Principis officiis consiliasse sibi?

Attamen his unum deerat, quod longa senectus,

Et gravis in terris cura negare solet:

Scilicet hic quaerens sibi semper in orbe quietem,

Posset ut a placida morte quiete frui.

Dixeris hinc etiam merito post fata beatum,

Omnia quae petiit si Polyander habet.

Ut quondam felix memorabile nomen Achillis,

Ejus Maeonide facta canente, fuit:

Sic te felicem, memori Spanhemius aevo

Dum cineres docto consecrat ore tuos.
A.M. à SCHURMAN. 
Így beszélt, s szavai nyomán szívemben heves vágy támadt, s keblemben fellobbant az iránta érzett szent szeretet lángja. Ettől kezdve képtelen voltam teljes bizalommal mást tanulmányozni, mint akiket különleges barátainak mondott. Közülük úgy ragyog ki a te neved, Fredericus, mint a Hold a kisebb csillagok között. Te járj előttem, s dalom nagyszerübb lesz, tán a fennkölt tragédiával is felér, te járj előttem, s dalom nagyszerübb lesz, mint Echo visszhangozza versengve a völgyhátról visszavert hangot, tanulékony ritmusom úgy igazítom szavaidhoz. Csak csobogjon Pegasus forrása, s éljenek a tudós Nővérek, az én Parnassusom te leszel, az én Phoebusom te leszel.

Utrecht, 1644. január 22.

\section{[26] A nemes és tiszteletreméltó teológus, Johannes Polyander van den Kerckhoven halálára}

Szerencsés agg, míg életed tartott, mily sors nem mosolygott barátságosan vágyaidra? Ki dicsekedhet vele, hogy érdeménél is több megtiszteltetés érte, melyeket a tudósaira halmozhat a szent toga? Ki látta nagyobb szerencsével nálad, hogy fiai a hatalmas fejedelem hivatalaiban tanácskoznak? Egy híja volt csak, s ezt a hosszú aggkor s a súlyos gond meg szokta tagadni ezen a világon: mindig is nyugalmat kívánt magának a földön, hogy békében nyugodhasson a békés halál után. Mondhatnánk, Polyander még e tekintetben is boldog halála után, ha mindent megkapott, mit kért. Mint a boldog Achilles neve örök, mert Maeonides énekelte meg tetteit, úgy téged, te boldog, Spanhemius bízott az örök emlékezetre, míg hamvaid tudós ajka szentelte meg.

Anna Maria van Schurman 
[27] Epicedium in obitum Doctrina et pietate Clarissimi Viri D. Meinardi Schotani

Qvis Schotane sibi te non suspiret ademptum,

Nec tua cygnaea funera voce fleat?

Qui tot divinis radiabas undique donis,

Queis potius nobis, quam tibi natus eras.

Quique novam ut posses mortalibus addere vitam,

Non piguit mortem te properare tuam.

Non sitis argenti, aut aliena negotia mundi,

Nec mora magnificae desidiosa dapis:

Sed tua coelestis qui viscera torruit ardor,

Is vetuit longos te numerare dies.

Ast licet aethereus penitus te carpserit ignis:

Hoc tamen, ut Phoenix, nasceris ipse rogo.

Dum vivet pietas, facilique modestia vultu,

Et nivea gaudens simplicitate fides;

Dum fera flexanimis demulcens pectora virtus,

Nomine nascetur gloria digna tuo.

Non tua sors lachrymas, sed nostra requirit, amaras:

Nam tua mors nobis, non tibi poena fuit,

Quis tanti referat capitis dispendia? velo

Ista tegi satius, more Timantis, erit.

At memorare tuos generosa in morte triumphos

Me juvat, et celsi munera laeta poli.

Illic dulce tibi veterum meminisse laborum:

Si tamen haec nullus sit meminisse labor.

Felix qui nostrum potuisti spernere mundum:

Quicquid felices reddit Olympus habet.

Omnia quae votis poscebas gaudia quondam, Iam datur in solo cernere mente Deo.

En tua quo praeeunt vestigia sponte sequemur.

Haec tibi nos tantum solvere justa cupis. 


\section{[27] Sírvers a kiemelkedően jámbor és tudós hírneves férfiú, Meinardus Schotanus úr halálára}

Ki ne sóhajtana fel, Schotanus, halálod hírére, s ki ne siratná hattyúi hangon végzetedet? Annyi meg annyi isteni adomány sugarától ragyogtál, mintha nem is magadnak, de értünk születtél volna. Halálodat sem restellted siettetni, hogy a halandóknak új életet adhass. Nem volt benned pénzéhség, nem törődtél evilág hozzád nem illö dolgaival, s nem fecsérelted időd nagyszerü lakomákkal. Csakhogy az égi hév, mely szívedet fütötte, nem engedte, hogy sok-sok napot számlálj. Noha a mennyei tüz teljesen átjárt, e máglyán mégis mint Phoenix kelsz új életre. Míg él jámborság s a kedves arcú szerénység s a patyolattiszta egyszerüségben kedvét lelő becsület, s míg a vad szíveket megindítja, s megszelídíti az erény, nevedhez méltó dicsőséged is lesz. Nem a te sorsodon, hanem a magunkén kell keserü könnyeket ejtenünk, mert halálod nekünk, s nem neked volt büntetés. Lehet-e rá szó, micsoda kár e fő elvesztése - boruljon rá lepel inkább, mint Timanthes festményén? Mégis jól esik most, nemes halálodkor, hogy eszembe jut diadalod, a magas menny ajándéka, a boldogság. Édes most neked ott, ha visszaemlékszel hajdani fáradozásodra, ha ugyan nem fáradság az is, hogy rájuk emlékezzél. Boldog vagy, ki meg tudtad vetni világunkat - a Mennyben minden megvan, ami csak boldoggá tehet. Mindaz az öröm, mit hőn óhajtottál hajdan, már megadatott, mert szellemed csakis Istent szemléli. Örömest követünk hát, amerre nyomaid vezetnek: vágyad az, hogy csak így adózzunk emlékednek.

A.M. van Schurman 
[28] In obitum summi viri D. Andreae Riveti, a morte Patris sui, in

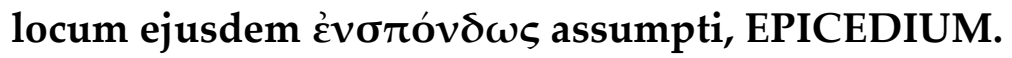

Dicite, Pierides, cur tanto pectora luctu

Plangitis, et maestos funditis ore modos?

Curque sedet pulla lugens sub veste Lyceum, Nostraque cur vultus Templa dolentis habent?

Gallia quem laetis surgentem vidit ab undis,

Et patrio placidum spargere in orbe jubar,

Hunc votis magnum venerata Batavia Solem,

Huc contra solitum currere fecit iter.

Hic modo Palladio, modo celsa fulsit in Aula;

Et tam diversis par tamen unus erat.

Vivida coelestis Doctrinae semina fovit,

Foecundaque novos messe beavit agros.

Et Romae coecas errorum dispulit umbras,

Restituens summo debita jura Deo.

Conspicuus semper Victor pugnavit in hostes,

Lucifugas telis perdidit ille suis.

Ipse sui similis, similisque per omnia Phoebo,

Omnibus auxilio, praesidioque fuit.

Nec tamen instabilem fas est dixisse Planetam,

Semper enim recto gestiit ire gradu.

Talis erat, misera quam flemus voce, Rivetus,

Qui sua funestis lumina mersit aquis.

Fallimur improvidae, non atris occidit undis,

Sed superum exoriens clarus in orbe micat.

Nec minus hic sanctae radiant vestigia vitae,

Et radiat scriptis author ubique suis.

Obstupui ad tristes, Musa referente, Cypressos;

Vix potis haec querulis verba sonare modis:

Siccine perpetuos patitur sors nostra regressus,

Et nostro ancipites versat in orbe vices.

Laetitiae finis dolor est; nihil usque beatum.

Munera quae Coelum contulit, umbra rapit.

Filia bis fueram felix: Horam ante supremam

Denasci natam bis, mea fata ferunt.

A.M. a Schurman 


\section{[28] Sírvers a kiváló férfiú, André Rivet Úr halálára, aki Atyja halála óta szerződés szerint az ő helyére vétetett}

Mondjátok, Pieridák, miért gyászoltok ily jajveszékeléssel s miért ont ajkatok gyászdalokat? Miért ül lesújtva sötét ruhában a Lyceum, s Templomaink orcája miért oly fájdalmas? Gallia volt tanúja, hogy e Nap fölbukkant boldog habjaiból, s szülőföldjén szórta simogató sugarait, mikor felnőtt, hőn tisztelte Batavia, majd a szokottól eltérő útra tért. Hol Pallas szentélyében, hol a magas Udvarnál tündökölt, $s$ bármily különbözők ezek, egymaga éppúgy illett mindkettőhöz. A mennyei Tudomány eleven magvait melengette, $s$ szántókat tört $s$ bő aratással boldogított. Róma tévelygésének vak sötétjét elüzte, visszaadta Istennek az őt megillető hatalmat. Mindig győztesen tűnt ki, ha az ellenség ellen harcolt, s dárdái elpusztították a fénygyülölőket. Önmaga volt, s egyben Phoebushoz mindenben hasonló, s mindenkit védett és oltalmazott. Égitestről mégsem mondhatjuk, hogy változékony - s neki is abban telt öröme, hogy egyenes úton járt. Ilyen volt Rivetus, kit most szánandó hangon siratunk, hogy fénye elmerült a halál tengerében. De mégsem: meggondolatlan tévedés ez, nem nyugodott le a fekete habokban, de fölkelt és szikrázva ragyog a Mennyek Országában. S éppúgy ragyognak itt is szent életének emlékei, s mindig is ragyogni fog mint írásainak szerzője. Az én hangom fennakadt, csak Múzsám szól a gyászciprusoknál, de még ő is alig bírja versbe önteni panaszszavát. Hát csak ennyire türi sorsunk a szűnni nem akaró visszatérést, s így gondol az árnyékvilágban az élet változásaira? Az örömre fájdalom jön, nincs örök boldogság. Amivel elhalmoz az Ég, elorozza a sötétség. Én kétszeresen is boldog leányod voltam, s így sorsom, hogy már végórám előtt meghaljak én, aki kétszer születtem.

A.M. van Schurman 
[29] In obitum Reverendi Clarissimique Viri, D. Caroli Dematii S.

S. Theologiae in celeberrima Academia atque Eccles. Ultraject. Mystae fidelissimi.

Ultrajectinum, rogitas, lugere Lyceum

Quid jubet, et nigra pulpita veste tegi?

Hic Sophiae colitur, toto celeberrima mundo,

Regia, quae geminum ditat utrimque Polum.

Bis senis radiat sublimibus alta Columnis,

Queis innixa jugis tendit ad astra suis.

Has inter trinas sibi jure dicavit Olympus,

In quibus insculpta est cernere jura Dei.

Sed venit ex alto tempestas saeva Tonantis,

Qua subito in praeceps de tribus una ruit.

Materies adamantis erat; quadrique figura;

Materiam summae vicerat artis opus.

Sit nunc prima Deum crescentis cura laboris,

Sacra ruat fulcro ne spoliata Domus.

Atlanti similis veniat Dematius alter,

Qui par sit tantas sustinuisse minas.
A.M. a Schurman 


\section{[29] A tiszteletre méltó és hírneves férfiú Carel de Maets halálára, aki a Szent Teológia hü tudora volt az Utrechti Akadémián}

Azt kérded, miért gyászol az Utrechti Lyceum, s emelvényeit miért vonták be fekete kárpittal? Ez Sophia palotája, leghíresebb az egész földön, gazdagítja a világ mindkét égtáját. Hat-hat oszlopon tör az égbe és szórja sugarát, rájuk hágva saját ormain tör a csillagok felé. E hármasság közepette méltán szentelték maguknak a Mennyek, feliratuk ezt hirdeti: „Nézd Isten törvényét!” De egyszer csak Tonans iszonyú vihart támaszt, s a háromból egy földre omlik. Anyaga gyémánt, alakja négyszögű, s gyönyörü kivitele még anyagánál is szebb. Legyen az istenek első gondja növekvő aggodalmukban, hogy romba ne dőljön a Szent Palota megfosztva oszlopától. Jöjjön egy új Dematius, Atlaszhoz hasonló, ki képes lesz megszüntetni a fenyegető veszélyt.

A.M. van Schurman 


\section{A kiadás adatai:}

Nobiliss. Virginis Annae Mariae a Schurman Opuscula Hebraea, Graeca, Latina, Gallica, Prosaica et Metrica, Editio tertia auctior et emendatior. Ex Officina Johannis a Waesberge, Trajecti ad Rhenum, 1652.

\section{A versek ottani megjelenésének adatai}

[1] Amplissimo Doctissimoque Viro D. Jacobo Catzio: 'Ut cygnum resides perhibent intendere voces' $=$ Opuscula (1652), 294-5

[2] Ad D. Barlaeum: 'Quas ego pro tanto persolvam munere grates?' = Opuscula (1652) 296

[3] Clarissimo Viro, D. Andreae Riveto s.: 'Tanta tuae, Rivete, viget vox inclyta famae' = Opuscula (1652), 296

[4] [hozzá szóló] Annae Mariae a Schurmans Unioni. Ut minus lateat.: 'Quo te, Nympha, cui tam custodita, quousque' = Opuscula (1652), 297

[5] Ad occultum Apollinis cujusdam ad lucem me provocantis Oraculum Responsio: 'Magnum Musa virum sonat, utque ego sim quoque vates' = Opuscula (1652), 297

[6] A. Mariae a Schurm. Epigramma in Nobilissimi praestantissimique Viri, D. Constantini Hugenii Opus - Diurnum. Quod in gratiam lectissimae suae quondam Conjugis Dnae. Susannae a Baerle conscripsit.: 'Quaeris an haec claram mereantur carmina lucem' = Opuscula (1652), 298

[7] Ad Illustrem Virum Zulichemii Dominum.: 'Cur me mortalem poscunt tua carmina testem' = Opuscula (1652), 298

[8] A. M. a SCHURMAN. Ad Epigramma Viri [héber szó] D. Constantini Hugenii Zulichemi Toparchae quod sic habet.: 'Nomen habe, Schurmanna canit. Lepidissima virgo!' = Opuscula (1652), 299

[9] Responsio Annae Mariae a Schurman.: 'Hugenio cum non sit, nomine, clarior alter' = Opuscula (1652), 299

[10] ALIUD: 'Anne bonum credat, nequeam cum solvere, nomen? = Opuscula (1652), 299

[11] ALIUD: 'Quare tuum Constans, nostro vis cedere nomen? = Opuscula (1652), 299

[12] Ad serenissimam Angliae Reginam e puerperio nuper egressam A. CID ID XXXV. tempore hyberno: 'Quae tibi nunc gelido miracula nata Decembri' = Opuscula (1652), 300

[13] Inclytae et antiquae urbi Trajectinae Nova Academia nuperrime donatae gratulatur. Anna Maria a Schurman: 'Tu quae lege potens agris dominaris' = Opuscula (1652), 300

[15] Magni ac generosi animi HEROINAE GORNACENSI, Causam sexus nostri fortiter defendenti gratulatur Anna Maria a Schurman: 'Palladis arma geris, bellis animosa

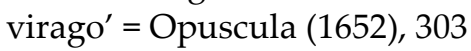




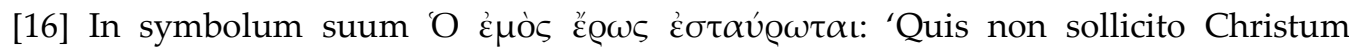
veneretur amore?' = Opuscula (1652), 303

[17] A. Mariae Schurman AD HXOY $\Sigma$ DOUSICAS Provocatio - Num a Nobilissimo Viro D. Dousa provocata, in lucem prodire debeat, necne?: 'O Vos Dousarum resonantes Carmina Nymphae' = Opuscula (1652), 304

[18] Clarissimo Ornatissimoque Viro, D. G. Staackmanno: 'Si veneranda docet frontem obvelare vetustas' $=$ Opuscula (1652), 304

[19] Apologia Annae Mariae a Schurman. Contra erroneos quosdam rumores, quibus propter nominis Schurmanni homonymiam, Astraeam d'Urse e Gallico in Belgicum sermonem vertisse creditur.: Cur mea lascivis praetexi nomina chartis = Opuscula (1652), 304-5

[20] Epigramma in Historiam Gelricam Clarissimi Viri, Joh. Isaaci Pontani.: 'Palladias artes quondam coluere Sicambri' = Opuscula (1652), 305-6

[21] Memoriae Celeberrimi Historici et Jurisconsulti Arnoldi Buchelii Eruditissimas Notas in Historiam Ultrajectinam Una cum vita finientis.: 'Gratia dum doctae fuerit mihi grata Minervae' = Opuscula (1652), 306

[22] In Reverendi, Nobilis Doctissimique Viri, D. Andreae Riveti S.S. Theologiae Doctoris Vindicias Mariae matris Domini.: 'Omnia sacrilegus tandem pervaserat error' = Opuscula (1652), 307

[23] Nobilissimo Doctissimoque Heroum D. Claudio Salmasio Felicem e Galliis redditum gratulatur Anna Maria a Schurman.: 'Hospes ave Batavis jam tandem reddite terris' $=$ Opuscula (1652), 308

[24] Reverendo, Clarissimo, Doctissimoque Viro, D. Friderico Spanhemio S.P.D. Anna Maria a Schurman: 'Quid me, Spanhemi, revocas Heliconis ad amnes' = Opuscula (1652), 309-12

[26] IN OBITUM Nobilissimi \& Venerandi Theologi JOHANNIS POLYANDRI à KERCHOVEN.: 'Fortunate Senex, quondam dum vita manebat' = Opuscula (1652), 314

[27] Epicedium in obitum Doctrina et pietate Clarissimi Viri D. Meinardi Schotani: 'Qvis Schotane sibi te non suspiret ademptum' = Opuscula (1652), 315

[28] In obitum summi viri D. Andreae Riveti, a morte Patris sui, in locum ejusdem

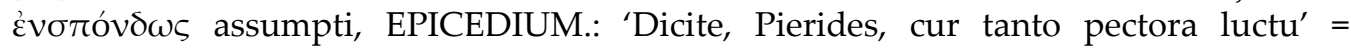
Opuscula (1652), 316-7

[29] In obitum Reverendi Clarissimique Viri, D. Caroli Dematii S. S. Theologiae in celeberrima Academia atque Eccles. Ultraject. Mystae fidelissimi.: Ultrajectinum, rogitas, lugere Lyceum = Opuscula (1652), 316-7 